Published in Theory and Struggle (Journal of the Marx Memorial Library) No 117, 2016.

\title{
What should socialists think about China?
}

\section{Gavin Poynter and Michael Rustin}

\section{Introduction}

The key issue to be considered in this article is the view socialists should take of the development of the Chinese People's Republic since its revolution in 1949 and more particularly since the death of Mao Zedong in 1976 and the emergence of the new Party leadership of Deng Xiaoping and his successors. These reflections have been prompted by the visits to China of the two authors. One of them (GP) made visits to China about ten years ago, soon after China's acceptance into the World Trade Organisation (WTO), for research exchanges connected with the London and Beijing Olympic Games. The other (MR) visited Beijing in the summer of 2015, to take part in a conference on mental health. Neither author brought much in the way of preconceptions or prior knowledge to their visits, nor were they involved in political discussions there. But each was astonished by the immensity of the development which they observed. They exchanged impressions, reflected on the seminars and conversations that they held with local state officials and professional people, and discovered much common ground in their appreciation of the dynamic character of China's recent development. These discussions have prompted this exploratory analysis.

There can be no doubt that socialist thought and practice in Britain and in other liberal democracies has long been influenced by what happens within socialist or communist systems in other parts of the world. Soviet and East European communism did not 
represent an attractive option for many in the West in the years before its collapse, but nevertheless its very existence effected some restraint on the power of capital to reshape societies to its own advantage. In the post-war period, the construction of European welfare states was in part motivated by the need to maintain popular support for capitalism in the face of a competing Communist system. Many democratic socialists were disappointed and demoralised by the failure of 'reform communism', first in Hungary in 1956 and Czechoslovakia in 1968, and then with the defeat and overthrow of Gorbachev in the Soviet Union in 1991. These developments had offered some hope that some new possibilities for socialism might emerge in the East, giving support to socialist aspirations in the West too. Subsequently, the fall of European Communism had the global triumph of neoliberalism as its immediate sequel, its principal adversary having been defeated. Since 1989, the main antagonist of global capitalism has become fundamentalist Islam in its various branches and locations, and socialists can find no reassurance whatever in that.

But there does, however, remain China, this immense and growing power which is ruled by a political party that still calls itself Communist, and which holds officially to the formula that its revolutionary leader, Mao Zedong, was ' $75 \%$ correct' in what he accomplished. This is after it has embraced, in its own earlier once condemnatory formulation, 'the capitalist road', and whose leader Deng Xiao actually or mythically proclaimed in 1978 that "to become rich is glorious."

The question we will be exploring is whether socialists have anything to learn from China's development. Does it represent a form of development alternative to capitalism, or is it merely its latest powerful recruit? Should the common liberal democratic critique of China's one party-state be simply endorsed by socialists, or might there be something to be said for a model of development which has given economic and social development a higher priority than multi-party democracy? Might the rise of China be reason for respecting a plurality of models of development, in place of a universalism centred on the West, which seems more than ever to have been captured by the ideology of capitalism, individualism, and free markets? 
One can sense a degree of hesitancy on the left about such questions. A history of shattered illusions - first regarding Stalinist Russia in the 1930s, then regarding Maoist China in its Great Leap Forward and Cultural Revolution periods, has led to a necessary caution in regard to the projection of left-wing hopes into far-off revolutions.

There is every reason for the left's caution during the second half of the twentieth century to persist into the new millennium. But it is also important that this attitude neither obscures attempts to understand the complexities of today's China nor, given the weak condition of the left in the West, kindles false hopes. What follows is an assessment of China's attempt 'to find its own way'.

\section{China and the "Soviet Model"}

There are significant differences between the Soviet and the Chinese context to point to. The first is that the regime has been astonishingly successful in transforming the living standards of its people, by any reasonable measure. That was not the case for East European communism, whose material achievements were very limited in comparison with the West's in the post-war period. The second is that the Chinese communists have recognised, as Lenin did in his short-lived New Economic Policy in the 1920s, that a successful hegemony depends on the support of, or coalition with, more than a single social class and corpus of interests. However Leninism was underpinned throughout subsequent Soviet history by the idea that the Communist Party represented the working class (and perhaps its agrarian equivalent) only, and that its essential mission was the struggle against all other classes. I have argued elsewhere (Rustin 2016) that this exclusionary doctrine has always licensed authoritarian rule, and in its more intense moments, a totalitarianism of elimination also.

It was of course the reaction of the Chinese Communist Party to the last phases of Maoism which set in train the different course which was set for China after Mao's death in 1976: this together with its reaction to the failure of the reform programme set in train in the USSR by Gorbachev in the 1980s. Indeed, one can interpret the entire Chinese development since its 1949 revolution as following from a determination to learn from the successive failures of the Soviet regime which followed the October Revolution of 1917. Maoism, on this reading, sought to bind the peasantry into the revolution, where 
Stalin had destroyed it. The Cultural Revolution was an attempt to pre-empt the bureaucratic degeneration of the Communist regime such as had set in the Soviet Union in the post-Kruschev period after 1964. Then the turn to capitalism, as early as 1976, recognised that a wholly state-controlled command economy would not be able to bring about economic parity with the West. The fact that Gorbachev's programme of reform led to the total collapse of Soviet and East European communism convinced the Chinese communists that the sequence of changes which had been pursued in the Soviet Union was the reverse of what it had needed to be.

The failure of the Soviet experiment in reform led to the rapid disintegration of the USSR and the appropriation by former Soviet 'officials' of the main sectors and institutions of the old Soviet economy. The Russian state was, after a period of chaotic transition, 'recaptured' by officials tutored in authoritarian ways and its power now rests in part on alliances between groups of oligarchs. Russia's experience has been studied by China's leaders, who appear to have drawn the conclusion that only once a level of economic development has been secured which brings living standards more-or-less to the level of the West, may it become safe to open up China's political system to contest and competition, since only then might the majority of the people remain loyal to the system in return for what it has achieved. From the perspective of China's leaders these do not seem unreasonable judgements. They are surely right in their expectation that any full opening of their system - including its media of mass communication - would be vigorously exploited by governments and other agencies in the West, with the aim of bringing it down entirely. Since World War 2 there have been too many interventions by the West aiming at what George W Bush called "regime change" for this to be in doubt. Agitations in the West for extended 'human rights' in China, despite their intrinsic moral merits, can also be interpreted as potential Trojan horses of western political infiltration and in Beijing's terms interference.

\section{Western Narratives}

There are two dominant political narratives in the West concerning China. The most powerful of these is liberal, though this covers a fairly broad span of attitudes and interpretations. From this perspective, the Chinese communist regime is essentially 
flawed, both ethically and, in the end, materially too. Its combination of an emerging market economy and an authoritarian system of one-party government is deemed to be essentially self-contradictory and unsustainable. At some point, the prediction is made, the political system will disintegrate or explode, ushering in a new 'democratic' dispensation which will bring China into the nirvana of capitalist democracy announced by Francis Fukuyama (1992) as "The End of History", and echoed in its substance by countless commentators. The more authoritarian turn being apparently taken by the regime under its new leader $\mathrm{Xi}$ Jinping, is taken as evidence that the regime recognises this risk to its future, but can find no way of responding to it other than by intensified repression. Some, both on the left and the right, hold that the protests of Tiananmen Square in 1989, about which the Chinese government remains acutely sensitive, might well have led by chain reaction in other cities to this to political disintegration, if they had not been suppressed.

Different chronologies are assigned to this supposedly inevitable replacement of one party communist government by multi-party capitalist democracy. One hitherto judicious China expert in the USA, David Shambaugh whose (2008) book on the Chinese Communist Party was well-informed and balanced in its assessment, recently (2015) posted an article in the Wall Street Journal predicting the imminent collapse of the regime, on the most shallow grounds. Will Hutton (2007) argues that in a world in which "democracy has become the international gold standard" ... "China is increasingly the outlier" with an "identity that will become ambiguous and difficult to manage." (P 22455) Martin Jacques (2009) is more deeply sympathetic to the Chinese achievement, and holds that 'the legitimacy of the Chinese state, profound and deeply rooted, does not depend on an electorate mandate." However, even he writes that "should the present experiment go seriously wrong....then the hand of history might come to rest on the Communist Party's shoulder, and its time be called." (P 425)

On the other side of the ideological debate about China are to be found Marxist, or Marxist-Leninist critiques of the post 1976 regime for effectively selling its communist soul to capitalism. From this position, the logic of the introduced market economy now seems unstoppable. A system already capitalist in all but name, seems at some point 
doomed to complete its journey down its capitalist path and to be taken over by all of its typical life-forms. In so far as any hope of an alternative is held out, this is assigned to working class resistance to a capitalist labour market, and to the other harms (for example to the environment) brought about by break-neck industrialisation and urbanisation. Hope is to be placed in the emergence of a genuine mass opposition movement, which must pit itself not only against employers, but also against the allegedly decayed and corrupted apparatus of the Party and its nomenclatura. As living standards rise, and the flow of rural migrants into the industrial labour force tails off, it is indeed reasonable to expect that the pressure of working class demands, for example for higher wages and improved working conditions, will grow. But it does not follow that most of the people making such demands desire to see the overthrow of the regime itself. On the contrary, polling evidence suggest that the Chinese government retains a high degree of legitimacy in the eyes of most of its people. (Bell 2015, p. 137).

Socialists in Britain, and elsewhere in Europe, long ago came to believe that representative democracy in the nineteenth and twentieth centuries was essentially the achievement of the organised working class, even though the institutions in which those demands were realised were those largely of constitutionalist liberalism. Raymond Williams (1961) memorably described the essence of the British working class movement as consisting in its democratic institutions and practices. From this point of view the translation of this collective democratic spirit into the 'managed democracy' of parliamentarism, was, as well as signifying a partial gain, also a failure. One question to be asked is whether those fractions of Chinese society which are today most committed to democratisation are primarily located in its working class, or rather in its new educated 'middle class' (the kindred spirits, one might put it, of the dissident artist $\mathrm{Ai}$ Weiwei). Might we be seeing a situation in China not unlike that in the 'post-modern' West whereby some of the most radical political activists are to be found among students and the most highly-educated young, working, often precariously, in cultural and informational industries in metropolitan areas, while the majority of the working class remains more conservative, in the sense of beingreluctantly supportive of governments on which it believes the protection of its living standards depends. 


\section{Rapid Accumulation}

It is important to take note at this point of how much the Chinese communist regime has in fact achieved for its people over the past four decades. An IMF Working Paper published in 2015 records that:

'China has grown at an astonishing rate of almost 10 percent per year, raising 660 million people out of poverty. Per capita income increased from $\$ 320$ in 1980 to about $\$ 5,500$ in 2012, and the number of people living on less than $\$ 1.25$ a day declined from 85 percent of the population in 1980 to 11 percent by 2012, according to the World Bank'. (IMF Working Paper Fiscal Affairs Department Growing (Un)equal: Fiscal Policy and Income Inequality in China and BRIC+ Prepared by Serhan Cevik and Carolina Correa-Caro, March 2015)

This development bears many of the hallmarks of earlier processes of industrialisation and urbanisation. It has been 'investment heavy' - that is to say a substantial 'surplus' has in one way or another been extracted from the labouring population to build the infrastructure and the machines needed to create a modern industrial nation. The visible presence of this in Chinese cities such as Beijing or Shanghai is astounding to see. There are immense numbers of modern buildings, highways, and railways, and an apparent absence in these cities of the sprawling slums and shanty towns that are to be found in megacities in other parts of the developing world, in Mexico City, Mumbai, or Cape Town. And at the other end of the chain of Chinese production, there is the abundance of cheap consumer goods which have flooded and taken over many of the markets of the West.

This has been and continues to be a process of 'primitive accumulation', with a labour force subject to extreme coercion (few rights of organisation. restrictions on migration and residence, severe labour discipline). A full analysis of the conditions that gave rise to China's rapid development are beyond the scope of this article but a few will be mentioned.

First, rapid industrialisation in China's eastern seaboard was supported by an abundance of labour drawn initially from the rural areas into the special enterprise zones and subsequently the major urban developments on the eastern seaboard. Statistics on migration within China have to be considered with care. The regulation of 
labour migration (the hukou system) distinguishes between rural and urban workers. The proportion of hukou migrants (those who moved to cities and retained their social and employment rights) has been relatively small compared to the 'non-hukou' migrants (those without such rights) of whom there were about 50-60 million in the early 1990s, 100 million by 2000 and around 150 million in 2009 (Chan 2011). This abundant supply of surplus rural labour has been critical to China's industrial development and is likely to continue to grow. It is estimated that of the current 800 million living in rural China (57\% of the population) a further 250 million will seek to move into cities and urban employment over the next five years, with the urban population reaching 70 percent of the total population by 2030. (World Bank 2014).

Second, China's opening up of its economy to foreign direct investment benefitted considerably from the investment undertaken by the Chinese diaspora particularly in the early phase of liberalisation of its economy (Min Ye 2014). Thirdly, China exploited its new status as a significant economic power especially through its relationship to the ailing US economy in the first decade of the new century. The 'special economic relationship' between China and the US that emerged enabled the latter's economy to act as a vast market for the consumption of manufactured goods. It helped to stave off international recessionary trends in the early years of the twenty first century, and assisted the US to sustain consumption at levels that reached new heights, fuelled by easily available credit to private consumers. This US consumption-led boom was, in practice, an example of a society living beyond its means, and it burst in the financial crisis of 2007-8.

The subsequent world-wide crisis led China to sustain economic growth since 2010 by turning to internal infrastructure investment fuelled by allowing local authorities to borrow to fund new projects. The weakness of the international economy and the domestic efforts to offset this through the expansion of credit within an immature financial system has given rise to several problems, not least a slowdown in domestic growth rates. However, present difficulties do not seem likely to undermine China's potential for continued growth, at least to the extent which some western observers have recently suggested. 
The regime is now reported to be changing the emphasis of its economic policy, to give greater priority to welfare provision such as in the fields of health and provision for the old, and to consumption within China rather than merely as the export of cheap commodities to be consumed in richer countries. Such enhanced public welfare provision meets several needs. The 'one child' policy ( recently revised) threatened many families with extreme risk in old age, since elderly parents hitherto counted on their grown-up children to look after them. Thus an expansion of state welfare provision has been a needed compensation. But there is also the fact that at a certain point economic development can only be sustained if the means of consumption as well as those of production are raised. Just as 'Fordism' in the West was supported by the development of 'welfare provision' in the twentieth century, so something similar seems to be about to take place in China in the twenty-first century.

One must surely see much that is to be admired in what has been achieved by this regime since its original revolution, and also since its embrace of a radical version of revisionism after 1976. The facts must be given their due weight. Average life expectancy has risen to 73 years for men and 77 years for women despite the absence of a universal health care system. Adult literacy rates rose from $77 \%$ to $95 \%$ between 1990 and 2015. Literacy among women has risen from $68 \%$ to $93 \%$ over the same period. Infant mortality rates have fallen from 29 infants per one thousand to around 15 per one thousand over the period 2000 to 2014 . The proportion of people living in what the World Bank defines as extreme poverty has fallen from $84 \%$ in 1981 to $12 \%$ of the population in 2010.

People justifiably talk about 'human rights', which is usually taken to mean freedom of speech, the rule of law, and representative democracy. But surely human rights have their material dimension too, in rights to subsistence, shelter, education, health, and a long life. Relevant here is Amartya Sen's 'capabilities approach', (Sen 1999) which assesses well-being by reference not merely to formal political rights (important as these are) or gross measures of per capita income, but rather by the basic entitlements which people possess, such as the above. Which, of India or China, countries with comparably immense populations but contrasting political systems, scores more highly 
in respect of human rights, when in one (China) average life expectancy at birth in 2013 was 74 (China) and in the other (India) it was 65?

\section{China's Social Relations}

The social transformations that have taken place in China suggest that there are specific characteristics to its path of social development which require careful interpretation. Whilst the general improvements in key social indicators outlined above are impressive, GDP per capita (one indicator of a nation's living standards) in China remains significantly lower than the USA. In 2013, for example, 'China's GDP per capita was $\$ 9,100$, whereas the US boasted a figure of $\$ 48,900$ ' (Sedghi: 2013). Clearly, while living standards have improved, there is still some distance for China to travel. Equally, the improvements in living standards and the reduction in poverty levels cannot disguise that China's development has taken place alongside a significant rise in income inequality.

Whilst 660 million have risen out of poverty, a wealthy 'middle class' or 'new rich' has also emerged as a recent World Bank Working Paper affirmed:

'But the fruits of the transition from a system of centrally planned socialism to a market-oriented economy are not being widely shared across the society. Income inequality-as measured by the Gini coefficient for pre-tax market income-has exhibited an increasing trend from 0.28 in 1980 to 0.44 in 2000 and 0.52 by 2013 . There is also significant within-China variation in income inequality at the regional level. This widening in the gap between rich and poor shows China's transition from a relatively egalitarian society to one of the most unequal countries in the world'. However, as this Working Paper continued to explain 'China's widening income inequality is largely a reflection of faster income growth among the rich, rather than stagnant living standards among the poor' (IMF ibid)

This qualification is an important one, growing inequality being of less account in a situation which the living standards of the poor are at the same time improving to a significant degree.

But the distinction between the rich and the rest of the population is but one dimension of the new social divisions that have emerged within China. A further profound distinction has arisen, paradoxically, from the Maoist commitment to eradicate social 
inequalities based on 'the three differences' between workers and peasants, the city and countryside and agricultural and industrial areas. The countryside was collectivised with land ownership and the implements of agricultural production moved from private to state ownership while cities became the site of production units through which all social and welfare provision was organised.

The hukou household registration system, introduced in 1958, divided people into urban or rural populations, thus restricting the movement of the latter into the cities, a move in part designed to reduce the pressures that uncontrolled migration to the city would create for the provision of employment and the modest social amenities organised by the enterprise and city based production units. In practice, the hukou system had significant effects upon social and class relations as they have changed during the phases of rapid industrialisation and urbanisation.

The divisions between rural and urban populations has tended towards breakdown with the rapidly developed eastern cities absorbing large numbers of formally 'rural' migrants seeking work in Chinese expanding industrial bases in areas like Shenzhen. A migrant or floating workforce was quickly created that moved into cities but was denied the registration rights to access essential services, including housing, and without the employment and welfare services provided by the urban production units. The migrant workforce has tended, especially over the past decade, to deploy extended family networks to facilitate movement into the cities. Many thousands have moved into areas of cities called 'urban villages'.

The first of these urban villages was established in the Pearl River Delta within the Shenzhen Special Economic Zone in 1978. Typically, the village was initially a rural area of land in which the farmers had no individual rights of ownership but did have collective rights to work and live on the land. On becoming a part of a rapidly expanding urban area, the villagers' rights (as a collective) were recognised by the state, and the collective would be compensated if their land was confiscated to facilitate urban infrastructure development.. It was to these urban villages, that thousands of migrant workers moved, living in the accommodation provided by the former (now landlord) 'farmers'. In the last two decades, the 'villages in the city' have provided essential 
accommodation for the migrant workforce, a source of significant income to an emerging landlord class and areas of high density housing units that have largely avoided the appalling conditions of the informal settlements that are a feature of cities in many emerging economies.

The urban village collectives became in effect shareholding companies that engaged with developers to exploit the rising land values spawned by rapid urbanisation. In effect, the consequence of attempts to centrally control the movement of labour, paradoxically, facilitated the emergence of multiple speculative developments that rested on rising land values and the emergence of a new landlord class of former farmers' collectives. (Lin et al 2011).

A further, and perhaps unique characteristic of the new social relations emerging in contemporary China has arisen from the process by which private enterprise has emerged alongside the state-owned sector. The state-owned sector has slowly but significantly shrunk as a proportion of the total economy, and is now concentrated in the large scale but often inefficient heavy industries. In the course of this transition, the basic form of social and work organisation, the 'production unit' has become less and less effective as the organiser and provider of the (Soviet-style) welfare, housing and educational provision for China's workforce. The consequence has been that local and national authorities have increasingly become responsible for elements of essential social and welfare provision. This transition is on-going and often patchy in its application but has been increasingly acknowledged as an important component of China's modernisation and of its capacity to sustain social cohesion.

In brief, the character of social relations within China's cities is significantly changing. A 'new rich' (entrepreneurial strata) has arisen from the emergence of a vibrant private sector and a 'professional' (sometimes referred to as a meritocratic) class has considerably expanded as it has assumed a significant role in developing the health, education and welfare structures that increasingly replace the old system of provision founded upon the work collective. And, within the vast category of lower waged labour, the 'floating' or (rural) migrant workforce has rapidly expanded (particularly in the early years of the twenty first century) but with the decline of the hukou registration system, 
the distinctions between this migrant population and other workers resident in China's vast cities is gradually eroding. Equally, the rising land values associated with urbanisation has witnessed the growth of numerous private sector occupations in the expanding service industries as well as a relatively prosperous landlord class.

The changes in social relations have taken a 'class character' but with some very specific features not least because the party and state has retained significant levels of control over social development and civil society despite the rising significance of the private sector. State and party affinities 'cut across' the public/private sector divide, lending the party and state apparatus a far greater weight, institutionally and socially, than a glance at the 'shrinking' role of the state in the nation's economy might suggest. And the concept of individual legal rights (in relation to, for example, property) remain relatively unclear in a society in which the ideological commitment to the 'collective' has diminished but not disappeared. In short, despite the decades of economic liberalisation, the state has sustained a high level of intervention in the affairs of civil society.

This is evident not least in relation to the status of women. In 1994 the Chinese State Council formally committed itself to the principle of the equality of the sexes, but in 2010, nearly two decades later, President $\mathrm{Hu}$ Jintao acknowledged that 'significant inequalities' persisted (Attaine 2012). Improvements in educational attainment and the provision of health care have been achieved though there are still substantial differences between urban and rural areas (in 2010 the percentage of women with a secondary school education was $54 \%$ in urban but only $18 \%$ in rural areas). In relation to employment, the majority of women rural workers are employed in the low paid agricultural sector and, in urban areas, women are most likely to be employed in lower skilled occupations. The demise of production units in urban areas has witnessed a modest fall in the proportion of women employed (from $77 \%$ in 1990 to $67 \%$ in 2010 (Attaine 2012:8)) a fall often arising from the shift of employment from state enterprises to the private sector in the process of rapid 'primitive' accumulation.

China's unique 'one child policy' (forbidding, in an extraordinary extension of state power, families to have more than one child) was part of a strategy of primitive 
accumulation, in the sense that it forcibly accelerated the 'demographic transition' (to lower birth and death rates) that has invariably accompanied industrialisation wherever it has occured,throughout the world. The logic of the one-child family was to enlarge the adult labor force, and incentivise the development of the 'human capital' represented by the single child in a family. (When one visits places of leisure and tourism in China, one sees lavish care and attention being focused on many single children, in family groups often consisting of both parents and grandparents.) Whilst this policy ensured a higher proportion of women's participation in the labour force compared to other emerging nations, such as India, and provided a measure of control over population growth, the drive for economic development was clearly at the expense of the most basic rights of women, and men too. That the policy has recently been relaxed may be a step towards filling the gap between the state's formal commitment to gender equality and its practical implementation.

This brief review of the complex forces shaping China's contemporary social relations provides some indication of the sources of actual and potential conflict. The state's interventions to use compulsory measures to facilitate urban development, has given rise to countless disputes with urban and rural 'collectives' over the rights to land-use, compensation awards and so on. State officials, and their village counterparts have been accused of the abuse of their official roles, and corruption has been rife and the subject of official crackdowns at various intervals over recent years. The break-up, movement and closure of state-owned enterprises has also generated 'industrial disputes' with their workforces, whose concerns have not been solely based upon 'economistic' concerns about wages and employment but more broadly about the removal of the housing and amenities that their employment gave them access to. In this sense, exploitation is experienced less as the direct result of the bourgeoisie extracting surplus value and more as the authorities reneging on their commitment to the forms of social provision associated with the Communist Party's formal commitment to socialism.

One possible line of development for China is that the state will withdraw from the sphere of production, leaving that to private capital and the market, while retaining a 
dominant role in the field of reproduction, or 'welfare'. This would be similar to the division of functions within the 'mixed economies' of earlier social and indeed Christian democracies in Europe. An alternative model considered applicable to at least an earlier phase of China's development, (Nolan 2004) is that of 'market socialism', in which the state retains a large stake in the ownership of productive enterprises, while subjecting them to the disciplines of the market. A lot may depend on whether either of these models comes to prevail in the future.

\section{Doctrines and Development}

A larger comparison between kinds of social system across the world is now beginning to impose itself. It can hardly be ignored that since the Financial Crisis of 2007-8, the maintenance of equilibrium and a measure of growth in the global economy has largely depended on China. Without its earlier staggering annual growth rate of $9-10 \%$ and even with its 'alarmingly' lowered rate of around $7 \%$, there would have been the nearcertainty of a severe global recession. What does this situation have to say about the alleged superiority of the 'neoliberal model' (a global free market, unrestrained corporate power, the freeing of financial capital from all governmental constraints) to that of 'planned economies'? How is that this 'planned economy' (like that of the earlier Asian Tigers) can achieve rates of accumulation many times higher than those western nations, not least in western Europe, which have dismantled most of the capacity they once had to plan their economies? The comparative economic success of China now gives reason to call in question the functional superiority of the neoliberal economic model.

In face of this situation, since the 2007-8 financial crisis, some neoliberals have argued for an even more thoroughgoing implementation of their own market ideology. Neoliberals seem to be slow learners. Their present course of action is now leading mainly to stagnation, social polarisation, and regression to reactionary and highly dangerous forms of nationalism and xenophobia. It seems that a further crisis may be the precondition for necessary re-thinking and change. One profoundly hopes that such a crisis will be averted, or that if it occurs it will not bring about the catastrophe which followed the analogous crisis in Europe of the 1930s. 
The crucial lesson that may need to be learned is not be so much about the superiority of the specifically Chinese communist economic model to the neoliberal one, but rather the superiority of state-enabled development to the model of laisser-faire and free capital flows now practised and preached by the West. China may be best understood as one variety of a system whose larger kind is constituted by the Asian Tigers whose advance preceded China's. These include South Korea, Taiwan. Singapore, and before it encountered the problems of the last decade or so, Japan. The control of capital flows, and the nurturing of new industries until they became competitive, was the precondition of economic success in this entire region, and was in conformity with its cultures of social solidarity. By contrast, the liberation of western capital, during the 1980s, from all constraints on its location has led mainly to a catastrophic process of deindustrialisation, whose effects are visible from Detroit to Redcar.

The inequalities generated by the neoliberal economy are also ultimately to its disadvantage, Much of the West now suffers from an underlying deficit in consumer demand, since incomes for the working class (or middle class as the Americans call it) have for years remained stagnant, while the increased wealth accruing to the wealthy is to a greater degree saved or squandered. (This differential "propensity to consume" was the grounds for Keynes' critique of rentier-dominated economies). Reports that the raising of popular living standards is now a priority for the Chinese government, in order to rebalance internal and external demand for its productive outputs, seems to signify a degree of economic far-sightedness.

There is a paradox in contemporary western conceptions of China. It is, without doubt, the elephant in the global room. It is so large and dynamic an emerging power that everyone knows how much depends, for the whole world, on how it evolvesAnalysts ponder on whether the Chinese government makes the right decisions regarding China's future, even on whether its system can survive, but hardly anyone seems to ask whether it provides an example of government and development from which anyone else might learn.

This is especially an issue for socialists. Is China's system to be regarded as the last major survival of the Communist revolutions of the last century, or is now to be seen as 
Communist in name only, and essentially a system of state capitalism, destined soon to be more capitalism than state? Daniel A. Bell, who broadly admires the Chinese model and its achievements, has expressed the view (Bell 2015) that Communism in China is now largely an empty shell, effectively abandoned as an ideology even by the Communist Party which rules the country. His argument is that China is increasingly to be understood as a meritocracy, in which Confucian traditions of good, wise and expert government are seen to have much greater relevance than Marxism-Leninism, which he believes the Party itself finds irrelevant to its decision-making. In his view, the Party itself has become meritocratic in its operation, increasingly composed of the universityeducated, and using criteria of demonstrated capability to allocate positions of influenceBell looks forward to the time when the Chinese Communist Party might rename itself the Chinese Confucian Party, not that he believes this change is imminent. Martin Jacques has described China as a 'civilisational state', rather than a merely national, or imperial one, and both he and Bell seem correctly to recognise the importance of a deeply-rooted cultural tradition in shaping modern China. There does seem a differentce between China's sense of its own historical specificity, and the declared "universalism' of western political philosophies, both liberal and Marxist.. Where China oppresses other peoples, as it has done, for example in Tibet, or may threaten to do in regard to Taiwan, it does so on the grounds that these peoples are "really" Chinese, not because China's ideological system is deemed to be superior to everyone else's backwardness.

Of course with growing power, can come imperial ambitions. China is making substantial capital investments in other countries, for example in Africa and the Caribbean. Some fear that it will seek to expand its military and political power to protect these, although the current Chinese view is that economic development, not military expansion, is the precondition of stability. Just as China has sought to learn from what it saw as the errors of the Soviet Union, so now it may be choosing a different path to international influence than that of the United States, with its current destructive entanglements in the Middle East. Prediction in these matters is difficult, but it does seem possible that China's relationship to the wider world may base itself more on a 
sense of its uniqueness and difference, than on a mission of universal conversion or conquest such as the West has adopted. The "Westphalian" model of international relations upheld the sovereignty of states and their rights to maintain their own religious beliefs, following the treaty which ended a century of religious wars. We might reformulate this doctrine as "to each state, its own way of life' and conceive it as the least-worst way of conducting inter-state relations. Significantly better, that is, than the advocacy of "preventive wars' and 'regime changes", legitimated by the liberal imperialist idea that combinations of global threats and the claims of universal human rights now render the Westphalian system obsolete, as American international relations theorists such as Philip Bobbitt (2002) have argued.

There does seem to be embarrassment even in China regarding the relationship, if any, between its contemporary political thought and practice and the Marxism of its origins. While there is receptiveness in China to many academic discourses, including economics, political science and sociology, "western Marxism" does not seem to be one of them. Just as China appears to be more open to democratic practices at the local than at the central level of government, so it appears to be more intellectually open within an outer circle of its academy, than in the inner circle of its Party.

We wonder, however, whether there might not be a more creative kind of continuity between China's Communist past, and its present revolution, than both its sympathisers and critics might suggest. Is the commitment to social inclusiveness, and to the enhancement of the living conditions of the working population, not a legacy of Communism, as well as being influenced by Chinese imperial traditions of good government? Is the official position of the Chinese government that Mao was " $75 \%$ correct" merely a politic gesture of deference to an abandoned revolution, or does it rather affirm a significant continuity with its past? Might it still be that the theory of the modes and relations of production developed within the Marxist tradition has something to offer in the understanding of the modern Chinese social system, making possible the identification of conflicting interests and ideologies, and addressing the problems of how to contain and resolve them. Might one indeed regard the Chinese system as one in which a "dictatorship of the proletariat" which has achieved a major transformation in the 
lives of the people (although with catastrophic famine and social disruption and oppression in two of its phases) is now seeking a way to develop into a more inclusive system?

\section{China: finding its own way to cross the river?}

Before preaching to the Chinese, and indeed to everyone else, the superiority of its own systems of liberal democracy as an unquestioned political goal Western governments and peoples would do well to attend to the limited achievements and deficiencies of their own systems. For one thing, if their own systems were in reality more truly democratic, and were more able to govern their own societies successfully, their advocacy of their supposed principles might be more persuasive. Freedom of expression, the rule of law, and free access to information, is a necessary element of a good society, and people should without doubt have the power to choose those who govern them. But there is no single path of development towards these goals, and the catastrophic failure of many military interventions surely shows that they can rarely be achieved by force. "Globalisation' is represented to be an inevitable process of development, unifying the whole world, when it is in fact the representation of an ideology which privileges the power of capital and free markets. What we now need is greater respect for differences, and to respect the entitlement of different social systems to shape their own development.

It is of great importance, not least for socialists everywhere, how the political and civil institutions of Communist Party-ruled China will evolve. The Chinese Communist Party's orientation has for forty years been different from that of the Soviet Union, ever since the bourgeois class was admitted by Mao's successors to have a potentially constructive role in China's development. Deng Xiaoping offered a remarkable formulation of the Chinese road post-Mao Zedong, saying "We will cross the river by feeling the stones". It is not a bad idea that governments should aim, in the words of the psychoanalyst Wilfred Bion, to learn from experience.

\section{References}


Attane I. (2012) 'Being a Woman in China Today: A Demography of Gender' China Perspectives: No. 2012.4.

Bell, Daniel A. (2015) The China Model: Political Meritocracy and trhe Limits of Democracy. Princeton NJ. Princeton University Press.

Bobbitt, P.(2002) The Shield of Achilles: War, Peace and the Course of History. London: Allen Lane/ Penguin.

Cevik S. and C. Correa-Caro (2015) 'Growing (Un)equal: Fiscal Policy and Income Inequality in China', IMF Working Paper Fiscal Affairs Department, March 2015 ) https://www.imf.org/external/pubs/ft/wp/2015/wp1568.pdf

Chan, Kam Wing (2011) 'China, Internal Migration' in Ness I and P. Bellwood (eds.), The Encyclopedia of Global Migration, Oxford: Blackwell Publishing..

Fukuyama, F. (1992) The End of History and the Last Man. New York: Free Press.

Hutton, W. (2007). The Writing on the Wall. China and the West in the $21^{\text {st }}$ Century. London: Little Brown.

Jacques, M. (2009) When China Rules the World. London: Allen Lane.

Lin Y and B..De Meulder (2014) 'Stakeholder Alliances for Development' in B. De Meulder and K Shannon (eds), Villages in the City, Zurich: Park Books.

Mazzucato, M. (2015) The Entrepreneurial State. London: Public Affairs.

Min Ye (2014) 'Diasporas and Foreign Direct Investment in China and India' Cambridge University Press: Cambridge.

Nolan, P:.(2004) Transforming China: Globalisation, Transition and Development. London: Anthem Press.

Rustin, M.J. (2016 in press) 'The Totalitarian Unconscious', in M. ffytche and D. Pick, (eds) Psychoanalysis in the Age of Totalitarianism. London: Routledge.

Sedghi A. (2013) 'China v the US: how the superpowers compare' Guardian, Data Blog, Friday June 7, 2013, http://www.theguardian.com/news/datablog/2013/jun/07/china-ushow-superpowers-compare-datablog 
Sen, A. (1999) Development as Freedom. Oxford: Oxford University Press.

Shambaugh, D. (2008) China's Communist Party. London: University of California Press.v augh

Shambaugh, D. (2015) "The Coming Chinese Crack-up" Wall Street Journal, March 6 2015.

Williams. R. (1961) The Long Revolution. London: Chatto and Windus.

World Bank (2014) 'Urban China', International Bank for Reconstruction and

Development /The World Bank and the Development Research Center of the State Council,P.R.China;

https://www.worldbank.org/content/dam/Worldbank/document/EAP/China/WEB-Urban-

China.pdf 